Atouts et outils de l'ethnologie des techniques

\title{
Mise en forme, mise en volume des vêtements
}

\section{Françoise Cousin}

\section{OpenEdition}

Journals

Édition électronique

URL : https://journals.openedition.org/tc/613

DOI : $10.4000 /$ tc. 613

ISSN : 1952-420X

Éditeur

Éditions de l'EHESS

Édition imprimée

Date de publication : 1 septembre 1994

ISSN : 0248-6016

\section{Référence électronique}

Françoise Cousin, «Mise en forme, mise en volume des vêtements », Techniques \& Culture [En ligne], 21 | 1994, mis en ligne le 30 décembre 2005, consulté le 29 septembre 2022. URL : http:// journals.openedition.org/tc/613; DOI : https://doi.org/10.4000/tc.613

Ce document a été généré automatiquement le 29 septembre 2022

Tous droits réservés 


\section{Mise en forme, mise en volume des vêtements}

Françoise Cousin 